УДК 821.161.2

DOI: 10.31475/fil.dys.2020.10.28

НАТАЛІЯ ФАНЕНШТЕЛЬ, кандидат педагогічних наук (л. Хлельницький)

\title{
Семантико-граматичні особливості англійської терміносистеми когнітивної лінгвістики
}

У статті досліджено логічну систелність англійськой терлінологї когнітивної лінгвістики. В результаті аналізу матеріалу дослідження, котрил слугували терліни, взяті із словника, встановлено, що англійська терліносистела когнітивної лінгвістики, хоча ї є частиною словникового складу мови, має істотні відмінності від загальновживаної лексики. Ці відлінності виявляються передовсіл у протіканні лексико-селантичних процесів, які мають загальний характер, але $\epsilon$ індивідуальнили в толу розулінні, що селантичні зв'язки завжди об’єднують конкретні терліни, а їхні наслідки призводять до появи поліселічних терлінів, терлінів-синонілів, терлінів-антонілів тощо.В результаті дослідження лорббологічної структури терлінів було встановлено, що найбільш продуктивнил способол нолінацї в собері англійськой терлінологї когнітивної лінгвістики $є$ терлінологічні словосполучення. Аналіз словотворчих засобів виявив, що найпродуктивнішил способол творення англійських терлінів когнітивної лінгвістики $\epsilon$ аббіксальне терлінотворення, яке, на відміну від загальнолітературного, мае строгішу селантичну спеціалізацію словотворчих морбел $і$ моделей. Встановлено, шо на понятійнолу рівні найчисленнішою в англійській терлінологій когнітивної лінгвістики є група субстаниій, оскільки досліджувані терліни нолінують поняття когнітивноӥ лінгвістики.

Ключові слова: терлін, терлінологія, терліносистела, класибікація терлінів,когнітивна лінгвістика.

Постановка проблеми в загальному вигляді... У сучасну епоху стрімкого розвитку інформащійних технологій особливо гостро відчутна потреба вдосконалення системи передачі та обробки інформації. Інтенсивність інформаційно-комунікативних процесів призводить до значного збільшення кількості термінів як надійних знаків, що відображають дійсність, та їхнього активного проникнення у 
повсякденну мову. Постійна необхідність створення нових термінів, потреба в термінологічних словниках та термінологічному забезпеченні інформаційних систем, наявність багатозначних термінів стали причиною «термінологічного вибуху». Це в свою чергу призвело до переорієнтації лінгвістичних досліджень в бік термінології природничих та точних наук та послаблення уваги до вивчення терміносистем менш динамічних галузей людського знання. Одним із відносно молодих але важливих напрямів мовознавства, чия терміносистема залишається малодослідженою, $є$ когнітивна лінгвістика.

Аналіз досліджень $i$ публікацій... Виникнення когнітивної лінгвістики - це один з етапів загального методологічного поступу, що розпочався у науці про мову з кінця 50- х років XX століття. Як напрям мовознавства, що займається дослідженням взаємозв'язків між мовою, розумом та соціофізичним досвідом, воназародилася в $1970-\mathrm{x}$ роках у США і в подалышому мала значну кількість послідовників у Свропі, зокрема в Бельгії, Нідерландах й Німеччині. Заснування в 1989-90 роках Міжнародного товариства когнітивної лінгвістики та журналу «Когнітивна лінгвістика» ознаменувало зародження когнітивної лінгвістики як широко обгрунтованого, самосвідомого інтелектуального pyxy.

Найвагомішими у світовому дискурсі когнітивного напряму мовознавства є праці здебільшого американських вчених (Р. Карстон, Г. Кларк, У. Крофт, Р. Дірвен, В. Еванс, Р. Джекендоффр, Дж. Лакофрф, Р. Лангакер, Л. Талмі, Дж. Тейлор $[1 ; 2 ; 3 ; 4 ; 7 ; 8 ; 9 ; 10 ; 11 ; 19 ; 20]$ та ін.).Напрацювання мовознавців, зокрема словник термінів когнітивної лінгвістики В. Еванс [5], свідчать про розвиненість англійської термінології цієї галузі.

Термінологічний апарат української когнітивної лінгвістики перебуваєу стадії становлення.Розвиток ціеї галузі на теренах нашої країни пов'язуемо 3 такими науковцями, як-от: А. Мартинюк [14], М. Піменова [15], С. Потапенко [16] та ін. У контексті нашого дослідження слід відзначити наявність у вітчизняному мовознавчому просторі словника основних термінів когнітивно-дискурсивної лінгвістики (автор А. Мартинюк), який містить 27 термінів. Проте розвиток української термінології когнітивної лінгвістики потребує подальшого накопичення, осмислення та систематизації матеріалу. Оскільки в останне десятиліття спостерігаємо активізацію прямих запозичень із англійської мови, цей спосіб термінотворення слід розглядати як такий, що потребує ретельного вивчення. 
Форлулювання иілей статmі... Отже, метою дослідження $є$ виявлення семантико-граматичних особливостей англійської терміносистеми когнітивної лінгвістики задля уточнення, доповнення, узагальнення й конкретизації уявлень про структуру терміну і способи термінотворення.

Виклад основного матеріалу... Важливою у дослідженні терміну і термінології є теза про їхню системність. Водночас питання характеру цієї системності залишається контраверсійним.

Зокрема, А. Реформатський ідеальною термінологією вважає повністю впорядковану систему, в якій, знання терміну забезпечує знання місця в системі, а знання місця в системі - знання терміну [18]. Отже, термін, на його думку «мае бути як лексично, так і морфологічно строго систематичним, здатним до створення похідних і максимально прагматичним в плані нормальної і типової парадигми» [17, с. 54].

Питання системності термінології у своїх працях піднімали й інші вчені (Г. Винокур, В. Лейчик,Д. Лоттета ін. [12; 13]), які були прихильниками «концепщії змістової (семантичної) системності терміна». Їхня «жорстка» позищія щодо системності термінів привнесла чітке розмежування у розуміння змістової і лінгвістичної системності шляхом введення уточнювальних термінів «термінополе» i «терміносистема».

Проте характерною рисою і умовою, яка дозволяе терміну діяти за природними законами мови, залишаеться асиметричність. Томувсередині термінологічної системи відбуваються дихотомічні процеси та розбіжності, зокрема між історичністю їі формування та системною природою. Всі терміни, як правило, поділяють на дві основні групи:

1) власне терміни - ті, які були сформовані спочатку в процесі деномінації нового явища реальності, що відповідае концепції певної дисципліни, або взятої з іншої терміносистеми;

2) термінологічні слова - ті, що виникли в процесі трансформації загальної семантики слова.

У контексті демаркації терміну варто враховувати такі його характерні властивості, як-от:точність;істотність (висвітлення важливих аспектів поняття та відсутність помилкових асоціацій);простота;якість похідних або похідність (здатність легко створювати похідні слова);добре звучання;системна особливість або системність (відображення в позначенні приналежності до певного класу понять);органічна природа або органічність (відповідність орфографії та тенденціям мови);сумісність (здатність поєднуватись у 
термінологічні колокаціі);однозначність;номінативність (на відміну від описової ознаки);стислість.

Важкість відокремлення термінів від іншої лексики передовсім полягає у тому, що лише невелика кількість термінів володіють усіма перерахованими вище якостями, водночас як більшості з них частково або повністю бракує деяких ознак.

У зв'язку 3 інформаційною необхідністю ширшого охоплення i вивчення більшої кількості термінів, які забезпечують наукову комунікацію, все частіше застосовують «гнучкіший» підхід, який виокремлюе терміносистеми за чисто лінгвістичними ознаками. До таких ознак належать тематико-понятійні, семантичні, граматичні та інші особливості терміна.

В результатізастосування диференщійованого підходудо аналізу термінів, взятих зі словника В. Еванс,ми виявили, що на понятійному рівні англійські терміни когнітивної лінгвістики формують три таких понятійних категорії, як-от: категорія субстанцій, категорія властивостей, категорія процесів. Найчисленнішою виявилась категорія субстанцій (68\%), що відображає головну характерну властивість терміна - здатність виражати наукове, технічне або фахове поняття. Категорія властивостей в англійській терміносистемі когнітивної лінгвістики розвинена меншою мірю. Це головне термінислова, які представляють $12 \%$ її кількісного складу. Категорія процесів також є нечисленною - 20\% від загальної кількості термінів.

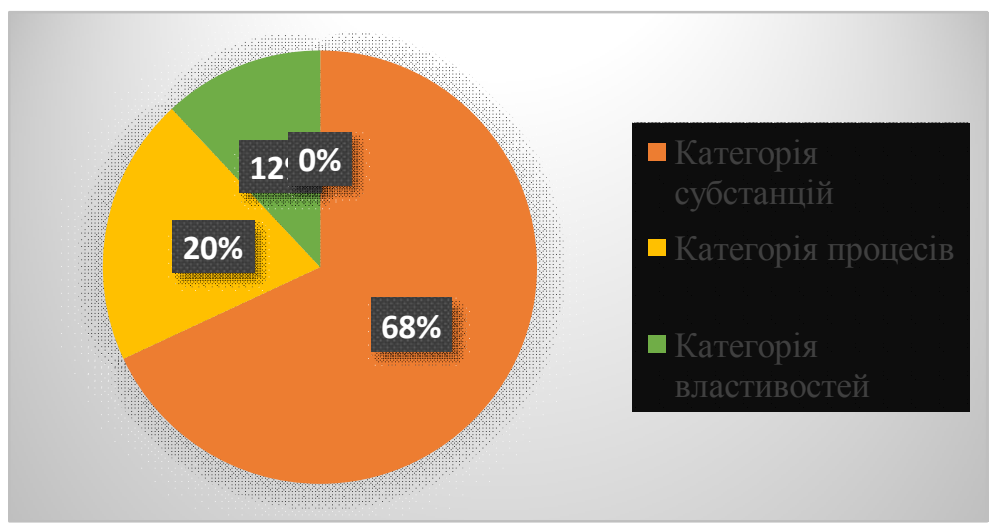

Рис.1 Телатико-понятійна класифікація англійської терлінологї когнітивної лінгвістики 
Оскільки термін - це не штучний знак, а слово чи словосполучення в особливій функції вираження спеціального поняття, в термінології відбуваються ті ж семантичні процеси, що i в лексиці загальнолітературної мови. Однак, протікання цих процесів в терміносистемах, а саме - полісемї̈, омонімії, антонімії, гіпонімії, гіперонімії - має низку особливостей.

До сьогодні в лінгвістичній літературі панує думка, що термін за своїм визначенням повинен бути однозначним. Проте практика дослідження різноманітних термінологічних систем свідчить про протилежне, оскільки терміну, як і будь-якій лексичній одиниці, властива багатозначність. Під полісемією прийнято розуміти наявність в одного і того ж слова деяких пов'язаних між собою значень, які найчастіше виникають внаслідок видозміни i розвитку первинного значення цього слова.

Кількість багатозначних термінів в англійській термінології когнітивної лінгвістики порівняно невелика. У результаті аналізу англійських термінів когнітивної лінгвістики на предмет полісемії, нами були виокремлені такі терміни, графічна форма яких співпадае із загальновживаними словам, як-от: access, activation, autonomy, base, blending, cognition, complex, direction, distance, figure, frame, schema, strength, Vehicle, world.

Наприклад, серед значень слова world(світ), яке за своєю природою є багатозначним, існують такі, як-от: 1) сукупність усіх фрорм матерї як єдине ціле; всесвіт; 2) окрема частина всесвіту; 3) земна куля; 4) людське суспільство, об'єднане певними соціальними, культурноісторичними та етнографічними ознаками; 5) певна галузь, сфера явищ природи; 6) певна галузь, сфера діяльності людей тощо.Як термін когнітивної лінгвістики слово world (cвim) позначае принципово нове поняття, характерне строго для ціеї галузі, а саме - теоретичний конструкт, який застосовують для моделювання уявлень людини про дійсність, про зміст речення і тексту.

Досить умовною є межа між полісемією та омонімією - звуковим збігом двох або більше мовних одиниць, різних за значенням. В термінології найбільш поширеною є міждисциплінарна омонімія, коли один і той самий термін входить до складу різних терміносистем мови. Серед англійських термінів когнітивної лінгвістики нами були виявлені як міждисциплінарні омоніми (cognitive mapping, common knowledge, consciousness, continuous, differentiation, episodic strategies, explanation, extension, generalization, instruction), так і омоніми, які фрункціонують в межах одніеї і тієї ж терміносистеми (abstraction, 
construction, Construction Grammar, domain, elaboration, fusion, ground, inheritance, target).

Термін відрізняється від звичайного слова тим, що він має певне означення і логічно визначає властивості, необхідні й достатні для вираження особливостей певного поняття, на яких побудованайого класифікація. Тому серед термінів набагато частіше, ніж серед загальновживаних слів, можна зустріти абсолютні синоніми. Термінологічній лексиці властиві такі види синонімів, як-от: термінидублети іншомовного походження, терміни-синтаксичні синоніми, дефініційні синоніми.

Найпоширенішими із перерахованих груп в англійській термінології когнітивної лінгвістики е терміни-синтаксичні синоніми, серед яких: comprehension - understanding (розуління), concept - notion (понятmя), evaluation - appraisal (оцінка, оціночне судження);а також такі дефініційні синоніми, як-от: belief system - belief (cuстела переконань - переконанна), deictic orientation - deictic system of spatial reference (егочентрична орієнтація - егочентрична систела просторової реберениії).

Головна причина виникнення і поповнення синонімічних рядів багатозначність терміна, а саме властивість багатозначних термінів входити до різних синонімічних рядів. Основними джерелами розвитку синонімії в термінах є такі мовні процеси, як-от: термінологізація, спеціалізація, метафоризація і метонімізація. До способів поповнення синонімічних рядів належать запозичення, калькування, переосмислення, застосування епонімів. Проблема полісемії і синонімії гостро відчутна при складанні зворотних словників, особливо коли способом визначення терміну є не науково дефініція, а синонімічний ряд.

Антонімію можна схарактеризувати як семантичну протилежність слів, а антоніми - як слова з протилежним значенням. В англійській термінології когнітивної лінгвістики, подібно до інших, антонімія постае одним 3 регуляторів принципів найменування понять 3 протилежним змістом.

Серед термінів-антонімів в досліджуваній терміносистемі відслідковуемо такі, як-от: antagonist (антагоніст) - agonist (агоніст), entry operator (onepamop входy) - exit operator (onepamop виходy), local knowledge (локальне знання) - global knowledge (глобальне знання) тощо.

Родово-видові відношення лексичних одиниць називають гіпонімією. Складниками цих відношень є слова-гіпоніми - ті, що 
виражають видові поняття, та слова-гіпероніми - ті, що виражають родові поняття. В термінологіях існують системні відношення між професійними поняттями, у яких зміст видового поняття $є$ ширшим від родового, а об'єм - вужчим. Відтак, значення слів-гіпонімів містить в собі більшу кількість семантичних компонент, аніж значення слівгіперонімів.

Відслідковуючи гіпонімічні відношення, які пронизують англійську термінологічну систему когнітивної лінгвістики, ми виділили структурно неоднорідні системи, серед яких зустрічаються родововидові мікросистеми мінімальної та ускладненої структур.
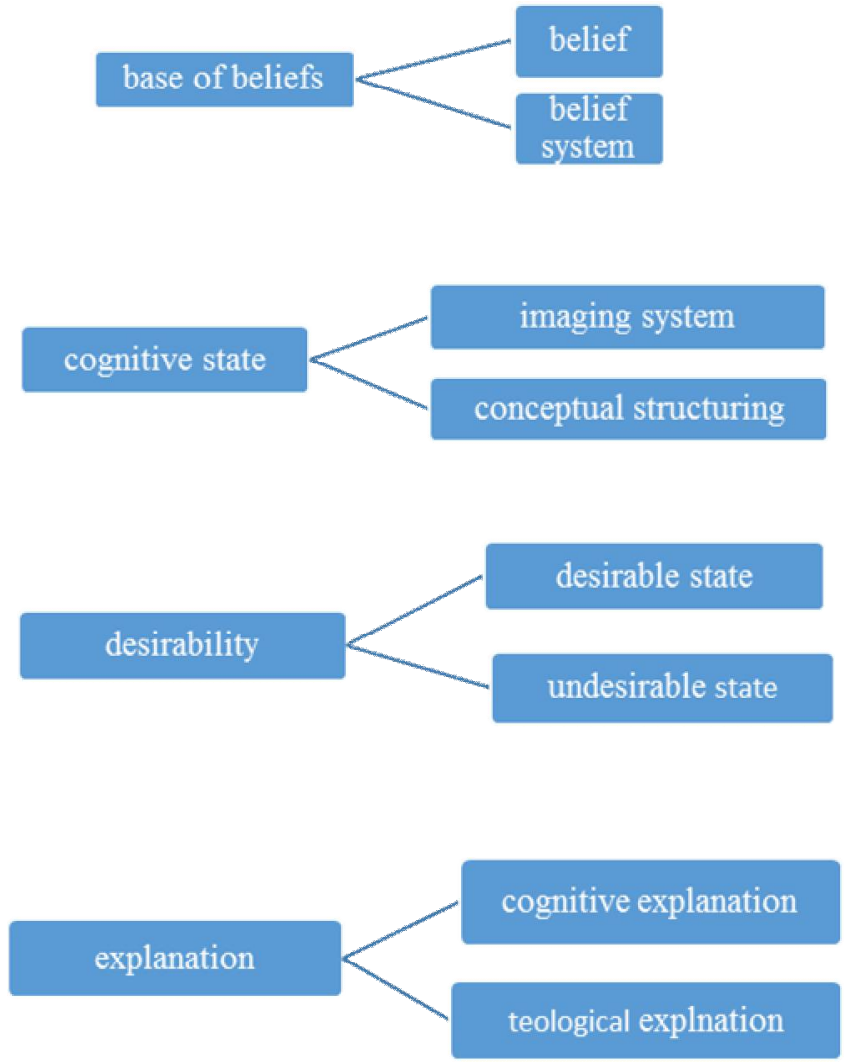

Рис. 2 Родово-видові мікросистели мінілальної структури (один гіперонім і два гіпоніми) 
Як правило, видові поняття в таких конструкціях мінімальної будови розмежовують на підставі ознаки ускладненості/неускладненості структури, первинності/непервинності походження, наявності/відсутності певної семантичної риси. У цих системах один термін видової опозиції маркуеться як такий, що має ознаку, на підставі якої розщеплюеться родовий термін, а другий протистоїть йому саме на підставі відсутності в нього вказаної ознаки.
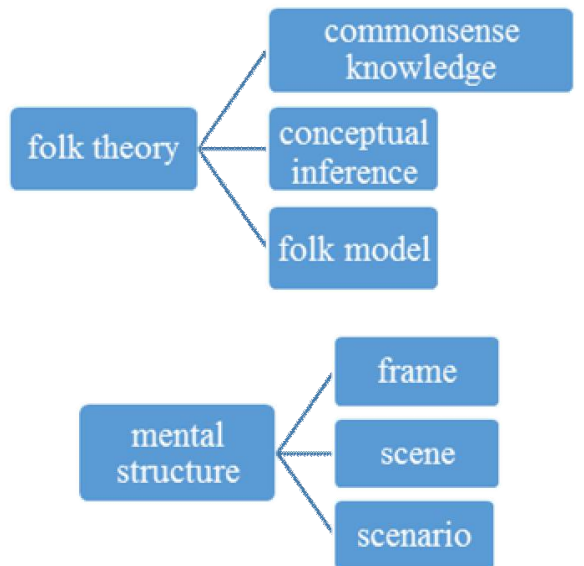

Рис. 3 Родово-видові мікросистеми ускладненої структури (із підпорядкуванням одному гіперонілу трьох гіпонілів)

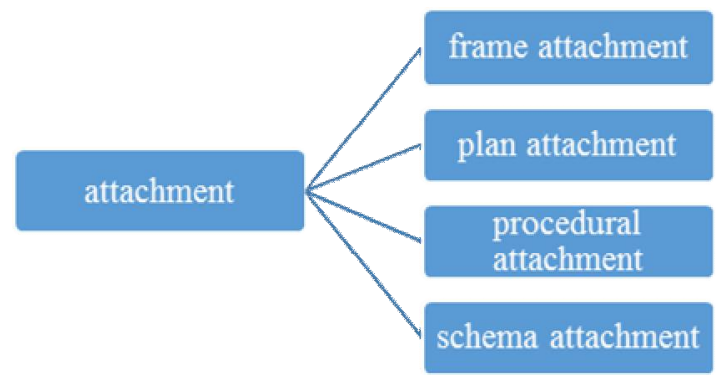




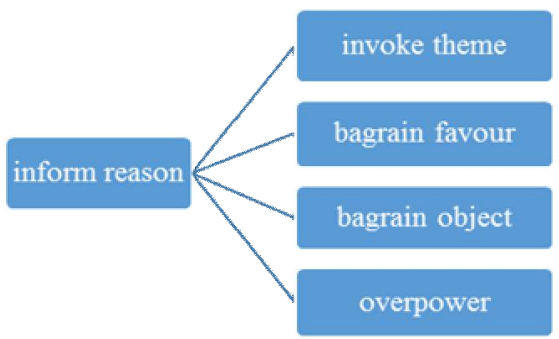

Рис. 4 Родово-видові мікросистели ускладненої структури (із підпорядкуванням однолу гіпероніму чотирьох гіпонімів)

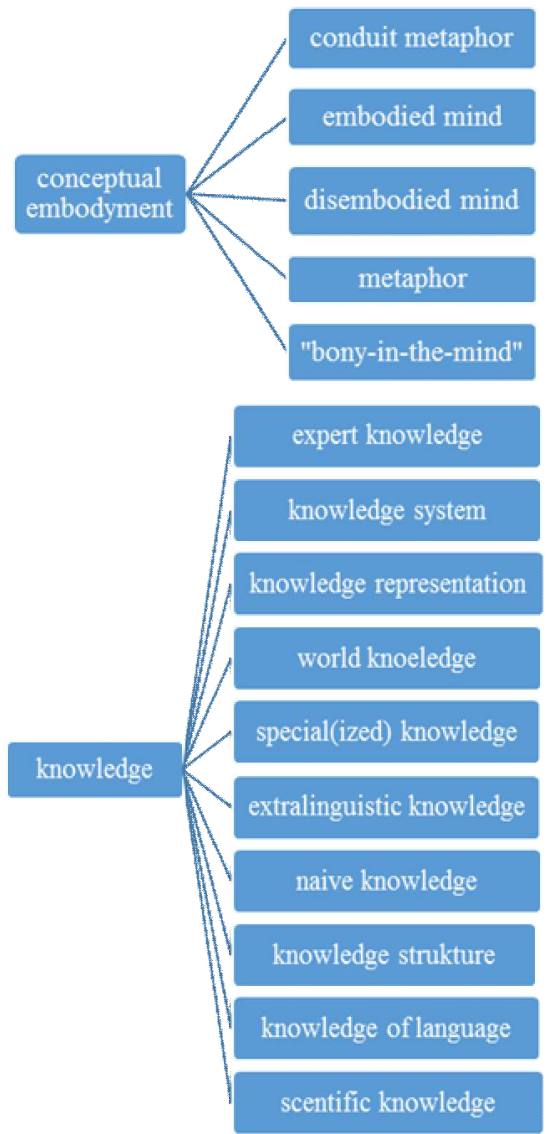

Рис. 5 Родово-видові мікросистели ускладненої структури (із підпорядкуваннял однолу гіперонілу п'ятьох і більше гіпонілів) 
Схарактеризовані семантичні процеси відбуваються в наукових текстах i призводять до появи полісемічних термінів, термінівсинонімів, термінів-антонімів тощо.Класифікацію термінів доцільно здійснювати і виходячи з їньої мордолого-синтаксичної структури, відповідно до якої зазвичай виокремлюють терміни-слова та термінисловосполучення.

Відповідно до морфемної структури, терміни-слова поділяють на непохідні, похідні, складені та абревіатури. Зокрема, серед англійських непохідних термінів-слів когнітивної лінгвістики знаходимо такі, як-от: concept, interest, loop, plan, fact, hope, idea, schema, script, state.

Значно більшою за чисельністю слів е група похідних, у яких словотворчі морфеми виконують класифікаційну фрункцію. До найбільш поширених способів словотворення в англійській термінології когнітивної лінгвістики належать предіксальний, суфіксальний та префіксально-суфіксальний.

Найбільш характерними для творення похідних термінів когнітивної лінгвістики є такі предікси, як-от: de-, dis-, inter-, in-, hypo-, meta-, proto-, re-, sub-, super-, un-. Вони визначають лексичне значення основи, проте рідко впливають на їі основну лексико-граматичну компоненту. Тому i непохідний, i його похідний термін належать зазвичай до одніеї і тієї ж частини мови (desirable - undesirable (бажаний - небажаний).

Особливе місце належить предіксам, які передають ідею заперечення (de-, dis-,un-). Англійські заперечні предікси мають різні відтінки значення i їх вживають з різними частинами мови. Однак, загальну ідею заперечення виражають префіксом dis-i вживають переважно $з$ діеслівними основами, наприклад: displacedconsciousness.

Велике значення у творенні англійських термінів когнітивної лінгвістики мають запозичені з класичних мов префікси (inter-, in-, hypo-, meta-, proto-, multi-, sub-, super-).Вони е особливо зручними для творення термінів в різних галузях, позаяк, через мертвість древньогрецької і латинської мов, їхня семантика постае в «законсервованому» вигляді. Позбавлені природних умов розвитку, греко-латинські мовні елементи стандартизуються і моносемуються, не обмежують свої словотворчі можливості й вживаються 3 різними частинами мови.

Суфіксальні моделі є найбільш характерними для термінологій, а суфіксальних похідних нараховують 60-70\% від загального складу терміносистем різних галузей.Для англійської терміносистеми когнітивної лінгвістики притаманними е такі суфікси, як-от: - ation, - 
tion/-ion, -ance/-ence, -able/-eble, -ment, -ist, -er/-or, -ity/-ty, -ize, ure.Значну частину суфіксальних термінів становлять іменники, які означають абстрактні поняття, дію, процес, стан, результат дії, інструмент, продукт діяльності (desirability, directness, explanation, focusing).

Особливий тип суфіксальних похідних - це похідні з частками up,in, on, off, down.Наприклад, в терміні backupчастка має словотворче значення, надаючи новому терміну відтінок одноразовості, а не поступовості дії.

Префіксально-суфіксальні моделі також притаманні англійській термінології когнітивної лінгвістики. Найчастіше тут зустрічаємо такі типи предріксально-суфіксальних утворень, як-от:

1) префікс + основа дієслова + суфікс (instruction)

2) предікс + основа іменника + суфікс (antagonist)

3) предікс + основа прикметника + судікс (interactivity).

Отже, для англійської терміносистеми когнітивної лінгвістики афіксальне термінотворення є продуктивним способом словотворення, яке, на відміну від загальнолітературного, має строгішу семантичну спеціалізацію словотворчих морфем і моделей. Це відображається в таких основних тенденціях словотворення, як-от:

- інтенсивному збільшенні власне термінологічного фонду словотворення, який забезпечуе одночасно і регулярність моделей, $\mathrm{i}$ спеціалізацію термінотворчих засобів;

- отенденції до гніздового словотворення, до створення комплексу найменувань, пов'язаних загальною твірною основою;

- посиленні в певних ситуаціях взаємозумовленості продуктивності словотворчої моделі.

Складені терміни-слова в англійській термінологічній системі когнітивної лінгвістики зустрічаемо значно рідше. Найтиповішою для окресленої терміносистеми є модель $\mathrm{N}+\mathrm{N}$ (іменник + іменник), яка є продуктивною i для загальнолітературної мови. Композиційно англійські складені терміни-слова представлені двома такими групами:

1. Сполучення двох елементів без сполучної компоненти (landmark).

2. Сполучення двох елементів прийменником або сполучником (body-in-the-mind).

Відсоток абревіатур є найнижчим в порівнянні з іншими моделями. Це явище можна пояснити тим, що англійські терміни когнітивної лінгвістики не належать до науково-технічної термінології. В матеріалі нашого дослідження терміни-абревіатури представлені лише одним 
складеним терміном-словом (ATN-grammar).

Як свідчать результати дослідження, словотворчий апарат термінології когнітивної лінгвістики не відрізняеться великою мірою від загальнолітературного. Проте англійська термінологія когнітивної лінгвістикина основі відпрацювання і відбору прийомів і ресурсів, які забезпечують словотворчо-фрункціональну якісність термінологічної лексики, створюе власну словотворчу підсистему.

Морфологічна структура термінів може бути різною, адже в текстах, як самостійно, так і в складі термінологічних словосполучень, фігурують терміни-іменники, дієслова, прикметники і прислівники. До словників та інших лексикографічних праць включають переважно іменники й іменні словосполучення, оскільки цей тип термінів називає предмети і виражає поняття про них; володіє високою частотою в науково-технічних і спеціально-продесійних текстах. Оскільки в якості матеріалу нашого дослідження був обраний словник термінів когнітивної лінгвістики, то більшість 3 них виявились іменниками (78 термінів) й іменними словосполученнями (230 терміносполучень).

Структура термінологічного словосполучення пов'язана 3 приналежністю його компонент до певних граматичних класів слів. Вона залежить від синтаксичної позиції складників й типу їхнього зв'язку зі стрижневим словом.

У нашому дослідженні англійські терміни-словосполучення когнітивної лінгвістики були класифіковані відповідно типу їхньої структури, а також морфології головного слова. В залежності від кількості компонент і характеру зав'язків між ними, ми виокремили прості (бінарні) словосполучення - ті, які складаються з двох слів, одне з яких є головним, а інше - залежним (family resemblance, lexical access, surface memory), та складені - ті, в котрих залежні слова визначають різні аспекти значення стрижневого (cognitive models of communication, intrinsic model of spatial reference).

Бінарні терміни-словосполучення е надзвичайно продуктивними, вони легко утворюються з слів найрізноманітніших предметних полів різних сфер загальної і спеціальної лексики. В залежності від морфологічного типу головного слова, прості терміни-словосполучення можна згрупувати в субстантивні, ад'єктивні та дієслівні. Найбільш притаманними для англійських термінів-словосполучень когнітивної лінгвістики $е$ прості та складені субстантивні словосполучення. Ад'єктивні та дієслівні не траплялися в силу того, що досліджувані терміни були вибрані зі словника.

В результаті дослідження було виявлено, що найбільш 
продуктивним способом номінації в сфрері англійської термінології когнітивної лінгвістики е термінологічні словосполучення. Вираження поняття складеним терміном не суперечить ані знаковій природі терміна, ані традиційному визначенню терміна як слова чи словосполучення, графічна (фонетична) оболонка якого відповідае певному поняттю в системі понять тіеї чи іншої галузі знань. Складений термін представляе один знак, який відповідає одному поняттю.

Висновки та перспективи подальших розвідок... Результати дослідження семантичних та граматичних процесів, що відбуваються в англійській термінологічній системі когнітивної лінгвістики, ілюструють той фракт, що термінологія, хоча й е складовою частиною словникового складу мови, все ж має істотні відмінності від загальновживаної лексики. Водночас терміни не $е$ ізольованими одиницями мови, які мають притаманні лише їм властивості, а складають ï повноцінну частину, де властивості слів виявляються більш визначено, регламентовано, відповідно до вимог професійного спілкування та взаєморозуміння. Отже, доцільно говорити про переважний характер властивості терміна порівняно із загальновживаним словом, а не про повну відсутність певної властивості. Можна стверджувати про бажані властивості термінологічної одиниці, проте не можна вважати її неповноцінною чи непотрібною лише на тій підставі, що вона не має певної властивості, хоча цей термін давно перебуває у вжитку користувачів.

Подальші дослідження проблеми є важливими для вирішення питань перекладу та унормування запозичених термінів, що беруть участь у формуванні української терміносистеми когнітивної лінгвістики.

\section{References:}

1. Carston R. Thought sandutterances: The Pragmatics of explicit communication. L. : Blackwell, 2002. 418 p.

2. Clark H. H.UsingLanguage.Cambridge : CambridgeUniv. Press, 1996. $436 \mathrm{p}$.

3. Croft W. Cognitivelinguistics. Cruse. - Cambridge :CUP, 2004. 356 p.

4. Dirven R. Cognitive Exploration of Language and Linguistics. Philadelphia : John BenjaminsPublishing Company, 1998. 301 p.

5. Evans V. The Structure of Time: Language, Meaning and Temporal Cognition. Amsterdam-Philadelphia : John Benjamins Publishing Company, 2003. 287 p.

6. Fillmore Ch. Some thought on the boundaries and components of linguistics. 
Talking minds: The study of language in cognitive science. Cambridge (Mass.), 1984. P. 73-108

7. Jackendoff R. Semantics and Cognition. Cambridge (Mass.) : MIT Press, 1993. $287 \mathrm{p}$.

8. Lakoff G. More than Cool Reason: A Field Guide to Poetic Metaphor. Chicago; London : The Univ. of Chicago Press, 1989. 230 p.

9. Lakoff G. Philosophy in the Flesh:the Embodied Mind and its Challenge to Western Thought. N.Y. : Basic Books, 1999. 602 p.

10. Langacker R. W. A usage-based model. Topics in Cognitive Linguistics. Amsterdam :Benjamins, 1988(a). P. 127-161

11. Langacker R. W. Foundations of cognitive grammar. Stanford : SUP, 1987(a). Vol. 1: Theoretical Prerequisites. 516 p.

12. Lejchik, V. M. and S. D. Shelov. (1989-1990). Lingvisticheskie problem terminology i i nauchno-tekhnicheskij perevod [Linguistic problems of terminology and science technical translation], part. 1-2. Moskva: Vysshaja shkola. [In Russian]

13. Lotte, Dmitrij S. (1961). Osnovy postroenija nauchno-tekhnicheskoj terminologii [Fundamentals of building the science and technical terminology]. Moskva: Izd-vo AN SSSR. 157 p. [In Russian]

14.Martyniuk A. Slovnyk osnovnych terminiv kognityvno-dyskursyvnoi lingvistyky [A Glossary of Cognitive-Discursive Linguistics],Kharkiv. :V. N. Karazin KNU, 2011. 196 p.[In Ukrainian]

15. Pimenova M. V. Terminology of cognitive linguistics: conceptual system and conceptual picture of the world. Terminolohichnyi visnyk. 2013. Vol. 2(1). Available at:http://nbuv.gov.ua/UJRN/termv_2013_2\%281\%29_15

16. Potapenko S.I. Introducing Cognitive Linguistics : [manual for students] Nizhyn: Nizhyn University Publishing House, 2013. 140 p. [In Ukrainian]

17. Reformatskij, A. A. (1961). Chto takoe termin i terminologija [What is term and terminology] In Voprosy terminologii [Questions of termiinology], ed. Ju. D. Desheriev, 46-54. Moskva: Izd-vo AN SSSR. 232 p. [In Russian]

18. Reformatskij, A. A. (ed). (1964). Lingvisticheskaja terminologija i prikladnaja toponomastika [Linguistic science and applied toponomastics]. Moskva: Nauka. 135 p. [In Russian]

19. Talmy L. The relation of grammar to cognition. Topics in cognitive linguistics. Amsterdam :Benjamins, 1988. P. 165-205.

20. Taylor J. R. Linguistic categorization. Prototypes in Linguistic Theory. Oxford : Clarendon Press, 1995. 310 p.

\section{Summary Nataliia Fanenshtel \\ Semantic and Grammatical Features of the English Terminology System of Cognitive Linguistics}

The paper deals with the logical system of the English terminology of cognitive linguistics. The analysis of the terms, that were taken from the glossary as the research material, has shown that the English terminology system of cognitive linguistics, although it is a part of the language vocabulary, differs significantly 
from the common words. The differences come out within lexical and semantic processes, which are general in their nature but individual in the sense that semantic relations always combine specific terms, and their consequences lead to the emergence of polysemic terms, synonyms, antonyms, etc. The research of the morphological structure of the terms has culminated in establishing the terminological collocations as the most productive way of nomination within the English terminology of cognitive linguistics. The analysis of the derivation means has indicated that the affixal way of term formation is the most productive. However, unlike general literature way, it has stricter semantic specialization of word-forming morphemes and models. It was found out that at the conceptual level the group of substances is the most numerous in the English terminology of cognitive linguistics, since the examined terms nominate the concepts of cognitive linguistics.

Key words: term, terminology, terminology system, classification of terms, cognitive linguistics.

Дата надходження статті: «21» жовтня 2019 р.

Дата прийняття до друку: «11» листопада 2019 р.

\section{УДК 81'42: 811.161.2+821.161.2.08 \\ DOI: 10.31475/fil.dys.2020.10.29}

ВАЛЕНТИНА ФІЛІНЮК, кандидат фбілологічних наук, дочент (л.Хлиельнииький)

\section{Сонце як компонент мовного полотна повісті «Небесний змій» Докії Гуменної}

У статті досліджено лексико-селантичні та стилістичні особливості фбункиіонування слова сонце у фбантастичній повісті Докії Гуленної "Небесний змій». Було використано фбункиіональноселантичний аспект для виявлення лексико-селантичних зв'язків між словали, семантичного наповнення лексел, актуалізацї різних сел для передачі авторського задулу. Було заббіксовано близько 80 випадків уживання слова сонче. Цей лексичний колпонент в аналізованій повісті значно розширив селантичне поле. Окріл, заббіксованих у словниках значень слова сонце, ми виявили такі семи: 'сторона світу', 'джерело світла', 'астронолічне поняття', 'борла', 'напрям руху', 'час', 'коло', 'візерунок', 'божество', 'людина'. Найчастіше Докія Гуленна пише про сонце як персоніббіковану 